\title{
Rapid regio- and multi-coupling reactivity of 2,3-dibromobenzofurans with atom-economic triarylbismuths under palladium catalysis
}

\author{
Maddali L. N. Rao*, Jalindar B. Talode and Venneti N. Murty
}

Open Access

\author{
Full Research Paper \\ Address: \\ Department of Chemistry, Indian Institute of Technology Kanpur, \\ Kanpur-208016, U.P., India, Tel/ Fax: +91-512-2597532 \\ Email: \\ Maddali L. N. Rao* - maddali@iitk.ac.in \\ * Corresponding author \\ Keywords: \\ bromobenzofuran coupling; cross-coupling; palladium; regio-selective; \\ triarylbismuth
}

\author{
Beilstein J. Org. Chem. 2016, 12, 2065-2076. \\ doi:10.3762/bjoc.12.195 \\ Received: 17 June 2016 \\ Accepted: 25 August 2016 \\ Published: 22 September 2016 \\ Associate Editor: I. Marek \\ (C) 2016 Rao et al.; licensee Beilstein-Institut. \\ License and terms: see end of document.
}

\begin{abstract}
A regio- and chemoselective cross-coupling study using 2,3-dibromobenzofurans and 2,3,5-tribromobenzofuran was achieved with sub-stoichiometric loadings of triarylbismuths as atom-economic reagents under Pd-catalyzed conditions. As part of this study, various 2,3-diaryl- and 2,3,5-triarylbenzofuran products were obtained in high yields, involving one-pot operations and short reaction times.
\end{abstract}

\section{Introduction}

The benzofuran scaffold is present in various biologically active molecules [1-8], natural products [9-15] and also part of various functional materials [16]. Importantly, 2,3-disubstituted benzofurans are biologically important (Figure 1a-d) and a few reports about their isolation and synthetic methods are available [17-19]. Substituted benzofurans serve as antitumor agents [20], protein tyrosine phosphatase-1B inhibitors [21], antimycobacterial agents [22] and as ambipolar materials (CZBDF, Figure 1c) [16]. To note, synthetic functionalization under transition-metal-catalyzed conditions allows the preparation of multi-substituted benzofurans in a facile manner [23-28]. Langer et al. reported the site-selective Suzuki-Miyaura reaction of 2,3-dibromobenzofuran with arylboronic acids under palladium catalyzed conditions $[29,30]$. Bach et al. reported site-selective studies involving the Sonogashira, Negishi, Kumada cross-couplings employing 2,3-dibromobenzofuran and 2,3,5-tribromobenzofuran substrates [31-33]. Additionally, Langer et al. reported the synthesis of 2,3-dialkenylbenzofurans and functionalized dibenzofurans with domino "twofold

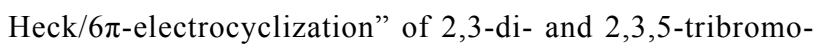
benzofuran substrates [34].

In this regard, the cross-coupling studies of triarylbismuth reagents in regioselective studies with functionalized bromobenzofurans were not reported so far (Scheme 1) [35]. Given the importance of threefold couplings' reactivity realized with the sub-stoichiometric loading of triarylbismuths in the crosscoupling reactions [35-42], we report herein, a novel regio- and 
<smiles>Oc1ccc(/C=C/c2cc(O)c3c(-c4cc(O)cc(O)c4)c(-c4ccc(O)cc4)oc3c2)cc1</smiles>

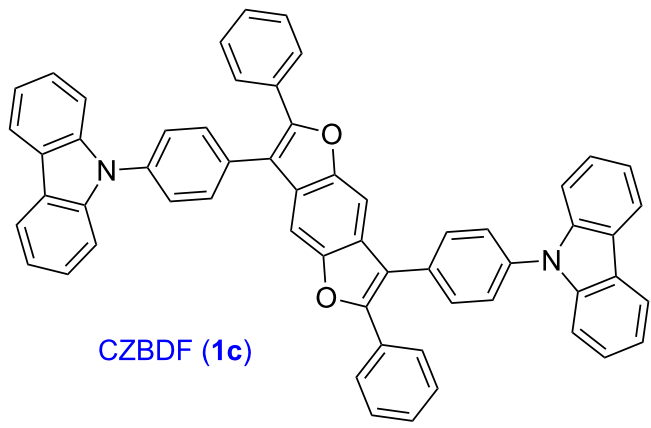<smiles>Oc1ccc(/C=C/c2cc(O)cc3oc(-c4ccc(O)cc4)c(-c4cc(O)cc(O)c4)c23)cc1</smiles><smiles>COc1cc(-c2oc3c(OC)c4oc(-c5cc(O)cc(O)c5)cc4cc3c2-c2cc(O)cc(O)c2)ccc1O</smiles>

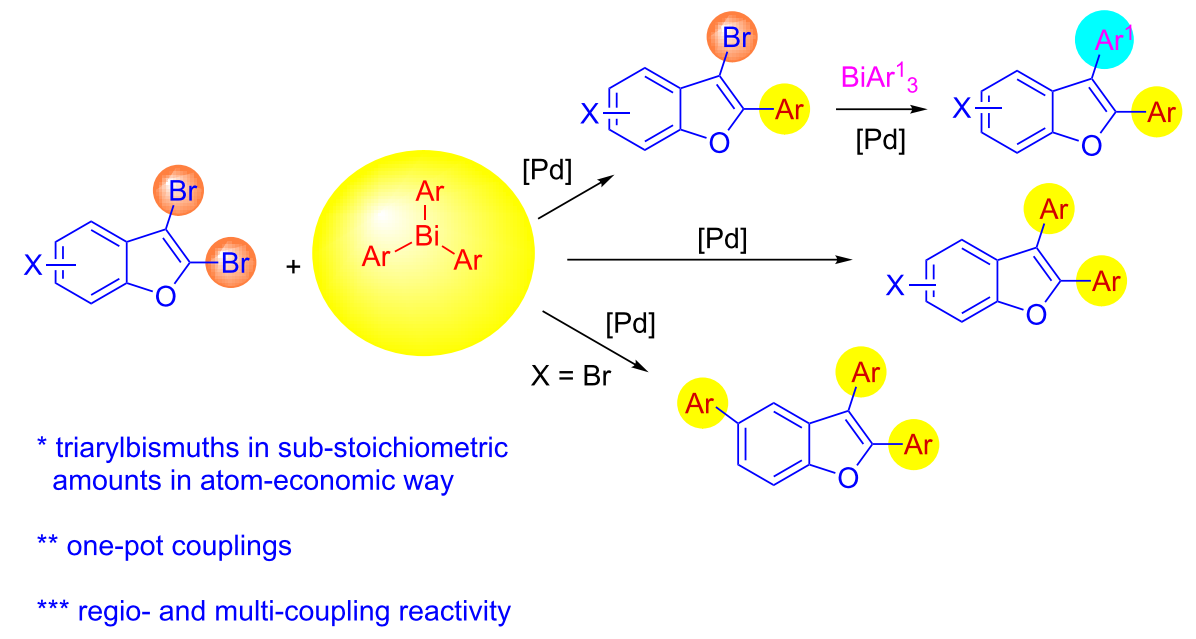

Scheme 1: Bis- and tris-couplings.

multi-coupling of bromobenzofurans with triarylbismuth reagents under palladium coupling conditions.

\section{Results and Discussion}

This study was initiated with 2,3-dibromobenzofuran for the investigation of the regio-selective coupling using a triarylbismuth reagent in substoichiometric amounts under Pd-catalyzed conditions (Table 1). A trial reaction was performed with 2,3dibromobenzofuran (1.1, 3.3 equiv) and tri( $p$-anisyl)bismuth (1 equiv) with $\mathrm{Pd}(\mathrm{OAc})_{2} / \mathrm{PPh}_{3}, \mathrm{Cs}_{2} \mathrm{CO}_{3}$ (3 equiv) in $N$-methyl- 2-pyrrolidone (NMP) at $90{ }^{\circ} \mathrm{C}$ for $1 \mathrm{~h}$ as protocol conditions [35]. This protocol furnished the preferential cross-coupling at the more electrophilic 2-Br position of 2,3-dibromobenzofuran (1.1) [29]. This reaction delivered 2-aryl-3-bromobenzofuran 2.1 in $46 \%$ yield (Table 1, entry 1) and the corresponding bisarylation product involoving both $2-$ and $3-\mathrm{Br}$ positions was not formed. Under similar conditions but with $\mathrm{Cs}_{2} \mathrm{CO}_{3}$ (4 equiv) as base, the cross-coupling yield was increased to $73 \%$ (Table 1 , entry 2). A further change in reaction time to $2 \mathrm{~h}$ raised the desired yield to $95 \%$ (Table 1 , entry 3 ). An additional check 
Table 1: Screening for mono-arylation. ${ }^{a}$<smiles>Brc1oc2ccccc2c1Br</smiles>

1.1

(3 equiv)
$\mathrm{Bi}(\longrightarrow-\mathrm{OMe})_{3} \stackrel{[\mathrm{Pd}]}{\longrightarrow}$<smiles>COc1ccc(-c2oc3ccccc3c2Br)cc1</smiles>

2.1

(3 equiv)

\begin{tabular}{cccccc}
\hline Entry & Base (equiv) & Solvent & Temp. $\left({ }^{\circ} \mathrm{C}\right)$ & Time $(\mathrm{h})$ & Yield (\%) (2.1) \\
\hline 1 & $\mathrm{Cs}_{2} \mathrm{CO}_{3}(3)$ & $\mathrm{NMP}$ & 90 & 1 & 46 \\
2 & $\mathrm{Cs}_{2} \mathrm{CO}_{3}(4)$ & $\mathrm{NMP}$ & 90 & 1 & 73 \\
3 & $\mathrm{Cs}_{2} \mathrm{CO}_{3}(4)$ & $\mathrm{NMP}$ & 90 & 2 & 95 \\
4 & $\mathrm{~K}_{3} \mathrm{PO}_{4}(4)$ & $\mathrm{NMP}$ & 90 & 2 & 61 \\
5 & $\mathrm{KOAc}_{4}(4)$ & $\mathrm{NMP}$ & 90 & 2 & 71 \\
6 & $\mathrm{Cs}$ & 90 & 2 & 80 \\
7 & $\mathrm{Cs} \mathrm{CO}_{3}(4)$ & $\mathrm{DMA}$ & 90 & 2 & 84 \\
8 & $\mathrm{Cs}_{2} \mathrm{CO}_{3}(4)$ & $\mathrm{NMP}$ & 110 & 2 & 47 \\
9 & $\mathrm{Cs}_{2} \mathrm{CO}_{3}(4)$ & $\mathrm{NMP}$ & 60 & 2 & $86^{\mathrm{b}}$ \\
10 & $\mathrm{Cs}_{2} \mathrm{CO}_{3}(4)$ & $\mathrm{NMP}$ & 90 & 2 & 05 \\
11 & $\mathrm{Cs}_{2} \mathrm{CO}_{3}(4)$ & $\mathrm{NMP}$ & 90 & 2 & 2 \\
\hline
\end{tabular}

${ }^{a}$ Reaction conditions: 2,3-Dibromobenzofuran (1.1) $0.825 \mathrm{mmol}, 3.3$ equiv), Bi(p-anisyl $)_{3}(0.25 \mathrm{mmol}, 1 \mathrm{equiv}), \mathrm{Pd}(\mathrm{OAc})_{2}(0.025 \mathrm{mmol}, 0.1$ equiv), $\mathrm{PPh}_{3}(0.1 \mathrm{mmol}, 0.4$ equiv), base $(0.75-1 \mathrm{mmol}, 3-4$ equiv), and solvent $(3 \mathrm{~mL})$, temp., time. Isolated yields based on three aryl couplings from BiAr 3 . Bianisyl formed in 5-15\% yields. bWith 2,3-dibromobenzofuran (1.1) (0.75 mmol, 3 equiv). ${ }^{c}$ Without Pd-catalyst.

with bases $\mathrm{K}_{3} \mathrm{PO}_{4}$ or KOAc did not furnish high yields (Table 1, entries 4 and 5). Investigations using solvents such as $N, N$-dimethylformamide (DMF) and $N, N$-dimethylacetamide (DMA) furnished lowered yields (Table 1, entries 6 and 7) in comparison with NMP solvent. Carrying out the crosscouplings at different temperatures also gave lower yields (Table 1, entries 8 and 9). Additionally, the stoichiometric combination of 3 equiv of 2,3-dibromobenzofuran (1.1) and 1 equiv of bismuth reagent gave $86 \%$ yield (Table 1, entry 10 ). A few control reactions without base or palladium catalyst showed inferior or no cross-coupling reactivity (Table 1, entries 11 and 12). This investigation results that the desired regio-selective cross-coupling reactivity could be obtained in excellent yield with $\mathrm{Pd}(\mathrm{OAc})_{2} / 4 \mathrm{PPh}_{3}$ (0.1 equiv) $\mathrm{Cs}_{2} \mathrm{CO}_{3}$ (4 equiv) in $\mathrm{NMP}$ at $90{ }^{\circ} \mathrm{C}$ and $2 \mathrm{~h}$ reaction time (Table 1 , entry 3 ) and it was considered as optimized protocol for our further study.

To check the generality of this regio-selective coupling, various 2,3-dibromobenzofurans have been tested with differently functionalized triphenylbismuth reagents under the optimized conditions (Table 2). This study was performed with triphenylbismuth reagents substituted with electronically activating and deactivating groups. The cross-couplings performed with these reagents demonstrated an excellent general reactivity (Table 2 , entries 1-12). It was highly satisfying to note that the corresponding products $\mathbf{2 . 1}-\mathbf{2 . 1 2}$ were obtained in $79-95 \%$ yields. It prompted us to extend our study to other functionalized 2,3dibromobenzofuran substrates. For example, a few bismuth couplings carried out with 2,3-dibromo-5-nitrobenzofuran (1.2) furnished the corresponding 2-aryl-3-bromobenzofurans 2.13-2.15 in 76-88\% yields (Table 2, entries 13-15). Additionally, we have also planned chemoselective couplings with differently functionalized 2,3-dibromobenzofurans. This study using 2,3-dibromobenzofurans functionalized with 5-chloro, 5,7-dichloro, 7-bromo-5-chloro and 5-bromo groups 1.3-1.6 furnished exclusive arylations at C-2 position.

In these cases, the corresponding 2-aryl-3-bromobenzofuran products 2.16-2.27 were obtained in high yields (Table 2, entries 16-27). It is to be mentioned that, despite the known facile coupling nature of aryl bromide [42] and its presence as part of the substrate, we obtained high regio-selective couplings with polyhalogenated benzofurans. The corresponding coupling products 2.22-2.27 were obtained in high yields (Table 2, entries 22-27). It is to be mentioned at this stage that in comparison to similar cross-couplings carried out with aryl boronic acids [29], the present method with triarylbismuth reagents showed appreciable reactivity with threefold coupling advantage and extended substrate scope. The overall resulted regioand chemo-selective couplings encouraged us to investigate further arylation studies with triarylbismuth reagents. It is to note that, under these mono-arylation coupling conditions com- 
Table 2: Cross-couplings of 2,3-dibromobenzofurans with $\mathrm{BiAr}_{3}$ reagents. ${ }^{\mathrm{a}}$

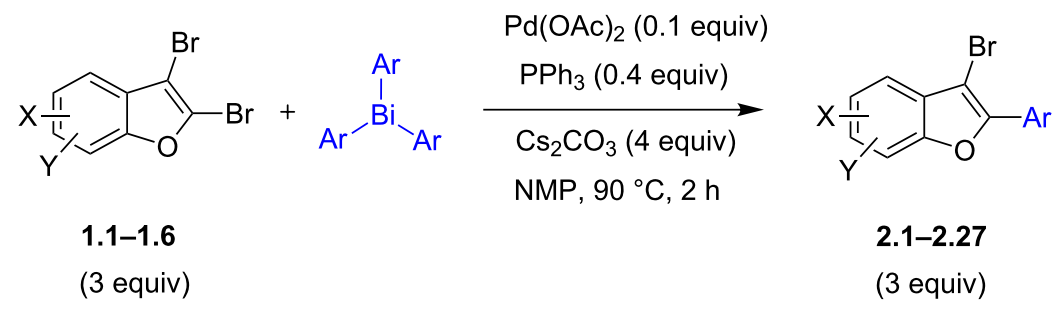

\begin{tabular}{|c|c|c|c|}
\hline Entry & 2,3-Dibromobenzofurans & 2-Aryl-3-bromobenzofurans & Yield (\%) \\
\hline
\end{tabular}

1<smiles>Brc1oc2ccccc2c1Br</smiles>

2<smiles>Brc1oc2ccccc2c1Br</smiles>

3<smiles>Brc1oc2ccccc2c1Br</smiles>

4<smiles>Brc1oc2ccccc2c1Br</smiles>

5<smiles>Brc1oc2ccccc2c1Br</smiles>

6<smiles>Brc1oc2ccccc2c1Br</smiles>

7<smiles>Brc1oc2ccccc2c1Br</smiles>

8<smiles>Brc1oc2ccccc2c1Br</smiles>

9<smiles>Brc1oc2ccccc2c1Br</smiles>

10<smiles>Brc1oc2ccccc2c1Br</smiles>

11

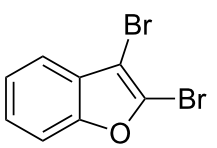

1.1<smiles>COc1ccc(-c2oc3ccccc3c2Br)cc1</smiles>

2.1

95

1.1<smiles>Brc1c(-c2ccccc2)oc2ccccc12</smiles>

2.2

88

1.1<smiles>Cc1ccc(-c2oc3ccccc3c2Br)cc1</smiles>

2.3

81

1.1<smiles>CCOc1ccc(-c2oc3ccccc3c2Br)cc1</smiles>

2.4

85

1.1<smiles>Clc1ccc(-c2oc3ccccc3c2Br)cc1</smiles>

2.5

89

1.1<smiles>Clc1cccc(-c2oc3ccccc3c2Br)c1</smiles>

2.6

86

1.1<smiles>COc1cccc(-c2oc3ccccc3c2Br)c1</smiles>

2.7

82

1.1<smiles>Fc1ccc(-c2oc3ccccc3c2Br)cc1</smiles>

2.8

93

1.1<smiles>Fc1cccc(-c2oc3ccccc3c2Br)c1</smiles>

2.9

90

1.1<smiles>Cc1cccc(-c2oc3ccccc3c2Br)c1</smiles>

2.10

79

1.1

2.11

92 
Table 2: Cross-couplings of 2,3-dibromobenzofurans with $\mathrm{BiAr}_{3}$ reagents. ${ }^{\text {a }}$ (continued)

12<smiles>Brc1oc2ccccc2c1Br</smiles>

1.1<smiles>O=[N+]([O-])c1ccc2oc(Br)c(Br)c2c1</smiles>

1.2

13<smiles>O=[N+]([O-])c1ccc2oc(Br)c(Br)c2c1</smiles>

1.2<smiles>O=[N+]([O-])c1ccc2oc(Br)c(Br)c2c1</smiles>

1.2<smiles>Clc1ccc2oc(Br)c(Br)c2c1</smiles><smiles>Clc1ccc2oc(Br)c(Br)c2c1</smiles>

1.3<smiles>Clc1ccc2oc(Br)c(Br)c2c1</smiles>

1.3<smiles>Clc1ccc2oc(Br)c(Br)c2c1</smiles>
1.3

20<smiles>Clc1cc(Cl)c2oc(Br)c(Br)c2c1</smiles>

1.4

21<smiles>Clc1cc(Cl)c2oc(Br)c(Br)c2c1</smiles>
1.4<smiles>Clc1cc(Br)c2oc(Br)c(Br)c2c1</smiles>
1.5 23<smiles>Clc1cc(Br)c2oc(Br)c(Br)c2c1</smiles><smiles>CC(C)Oc1ccc(-c2oc3ccccc3c2Br)cc1</smiles>

2.12

93<smiles>Cc1ccc(-c2oc3ccc([N+](=O)[O-])cc3c2Br)cc1</smiles>

2.13

82<smiles>CCOc1ccc(-c2oc3ccc([N+](=O)[O-])cc3c2Br)cc1</smiles>

2.14

88<smiles>Cc1cccc(-c2oc3ccc([N+](=O)[O-])cc3c2Br)c1</smiles>

2.15

76

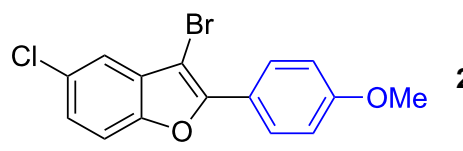

2.16

91<smiles>COc1ccc(-c2oc3ccc(Cl)cc3c2Br)cc1OC</smiles>

$2.18 \quad 87$<smiles>Clc1ccc2oc(-c3ccc4c(c3)OCO4)c(Br)c2c1</smiles><smiles>Clc1ccc2oc(-c3ccc4ccccc4c3)c(Br)c2c1</smiles>

2.19

63<smiles>COc1ccc(-c2oc3c(Cl)cc(Cl)cc3c2Br)cc1</smiles>

2.20<smiles>Cc1ccc(-c2oc3c(Cl)cc(Cl)cc3c2Br)cc1</smiles>

79<smiles></smiles>

70<smiles>[R16][R18]([H])([14CH3])c1ccc(-c2oc3c(Br)cc(Cl)cc3c2Br)cc1</smiles> 
Table 2: Cross-couplings of 2,3-dibromobenzofurans with $\mathrm{BiAr}_{3}$ reagents. ${ }^{\text {a }}$ (continued)

24<smiles>Clc1cc(Br)c2oc(Br)c(Br)c2c1</smiles>

25<smiles>Brc1ccc2oc(Br)c(Br)c2c1</smiles>

26<smiles>Brc1ccc2oc(Br)c(Br)c2c1</smiles>

27<smiles>Brc1ccc2oc(Br)c(Br)c2c1</smiles>

1.5<smiles>Cc1ccc(-c2oc3c(Br)cc(Cl)cc3c2Br)cc1</smiles><smiles>COc1ccc(-c2oc3ccc(Br)cc3c2Br)cc1</smiles><smiles>Fc1ccc(-c2oc3ccc(Br)cc3c2Br)cc1</smiles>

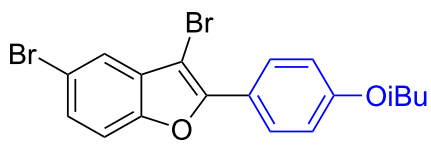

2.24

2.25

2.26

68

92

2.27

77

aReaction conditions: 2,3-Dibromobenzofurans ( $0.825 \mathrm{mmol}, 3.3$ equiv), $\mathrm{BiAr}_{3}$ (0.25 mmol, 1 equiv), $\mathrm{Cs}_{2} \mathrm{CO}_{3}(1 \mathrm{mmol}, 4 \mathrm{equiv}), \mathrm{Pd}(\mathrm{OAc})_{2}$ (0.025 mmol, 0.1 equiv), $\mathrm{PPh}_{3}\left(0.1 \mathrm{mmol}, 0.4\right.$ equiv), NMP $(3 \mathrm{~mL}), 90^{\circ} \mathrm{C}, 2 \mathrm{~h}$. Isolated yields based on three aryl couplings from BiAr 3 . Biaryl from $\mathrm{BiAr}_{3}$ formed in minor amounts.

prising an 1:3 stoichiometric ratio of $\mathrm{BiAr}_{3}$ :dibromide combination we have not obtained the formation of any bis-arylated product. Hence, it was of interest to explore towards a one-pot bis-coupling method to synthesize 2,3-diarylbenzofurans using 2,3-dibromobenzofuran which involves couplings at both 2-bromo and 3-bromo positions. With this aim, it was investigated with appropriate sub-stoichiometric amounts of triarylbismuth reagents to obtain bis-coupling product (Table 3 ).

Our initial attempt with mono-arylation catalytic conditions but with stoichiometric amount of bismuth reagent afforded 2,3- diarylbenzofuran $\mathbf{3 . 1}$ in 54\% yield along with mono-arylated $\mathbf{2 . 3}$ in $31 \%$ yield (Table 3, entry 1). Importantly, this bis-coupling process was expected to go firstly through the formation of a mono-arylated product followed by its involvement in a second coupling with bismuth reagent. Hence to improve the bis-coupling process, a brief screening was performed under similar conditions but with $4 \mathrm{~h}$ reaction time. This gave the desired biscoupling in $72 \%$ yield along with minor amount of monoarylated product (Table 3 , entry 2). It was further increased to $77 \%$ at $110^{\circ} \mathrm{C}$ in $2 \mathrm{~h}$ conditions (Table 3, entry 3) along with mono-arylated product $\mathbf{2 . 3}$ in minor amount. Hence, these

Table 3: Screening for bis-arylation. ${ }^{a}$

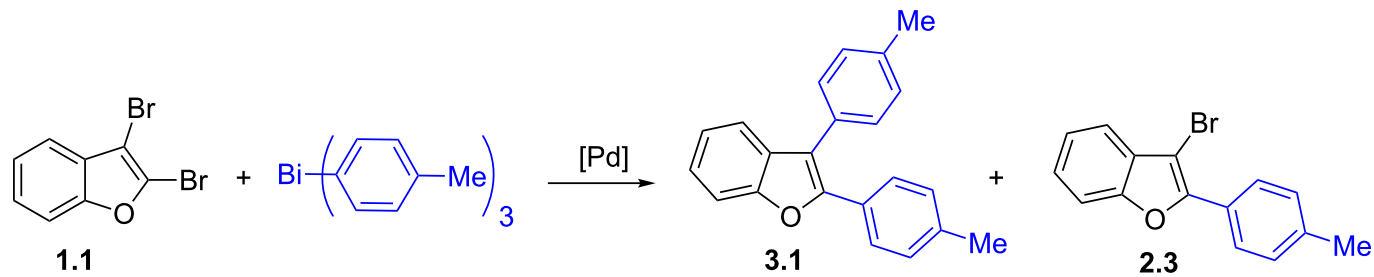

\begin{tabular}{ccccc}
\hline Entry & Catalyst & Temp. $\left({ }^{\circ} \mathrm{C}\right)$ & Time (h) & Yield (\%) $)^{\mathrm{b}} \mathbf{3 . 1}(\mathbf{2 . 3})$ \\
\hline 1 & $\mathrm{Pd}(\mathrm{OAc})_{2} / 4 \mathrm{PPh}_{3}$ & 90 & 2 & $54(31)$ \\
2 & $\mathrm{Pd}(\mathrm{OAc})_{2} / 4 \mathrm{PPh}_{3}$ & 90 & 4 & $72(4)$ \\
3 & $\mathrm{Pd}(\mathrm{OAc})_{2} / 4 \mathrm{PPh}_{3}$ & 110 & 2 & $77(2)$ \\
\hline
\end{tabular}

aReaction conditions: 2,3-Dibromobenzofuran (1.1) (0.375 mmol, 1.5 equiv), Bi(p-tolyl) $)_{3}(0.25 \mathrm{mmol}, 1 \mathrm{equiv}), \mathrm{Pd}(\mathrm{OAc})_{2}(0.025 \mathrm{mmol}, 0.1 \mathrm{equiv})$, $\mathrm{PPh}_{3}\left(0.1 \mathrm{mmol}, 0.4\right.$ equiv), $\mathrm{Cs}_{2} \mathrm{CO}_{3}$ (1 mmol, 4 equiv), NMP (3 mL), temp, time. blsolated yield (3.1) based on three aryl couplings from BiAr 3 . Bitolyl formed in $5-15 \%$ yields. Isolated yield of 2.3 given in parenthesis. 
conditions were adopted as optimized protocol for our bis-coupling study with triarylbismuth reagents (Table 4). Encouragingly, these bis-couplings using the established conditions afforded symmetrically substituted 2,3-diarylbenzofurans 3.1-3.7 in $72-85 \%$ yields (Table 4, entries $1-7$ ). In these cases, the corresponding mono-arylated products $(2.1-2.3,2.8,2.10)$ were also isolated in minor amounts. Evidently, this generalization of bis-coupling reactivity was proved to be operationally simple with high reactivity and yields involving $2 \mathrm{~h}$ short reaction time and with sub-stoichiometric loadings of the bismuth reagent. Incidentally, we could also obtain the X-ray structure analysis for diarylbenzofuran 3.1 as given in Figure 2. The ease of formation of symmetrically substituted bis-coupled products inspired us to additionally develop a viable procedure for the synthesis of unsymmetrically substituted bis-arylated benzo- furans. To accomplish this, we initially reacted 2-aryl-3bromobenzofuran $\mathbf{2 . 1}$ with bismuth reagent using the palladium protocol conditions established for symmetrical bis-arylations (Table 5).

It was carried out at $110{ }^{\circ} \mathrm{C}$ for $2 \mathrm{~h}$ and this furnished unsymmetrically substituted 2,3-diarylbenzofuran 4.1 in 54\% yield along with the recovery of starting 2-aryl-3-bromobenzofuran 2.1 in $42 \%$ yield (Table 5 , entry 1 ). As the reaction was found to be incomplete, a further investigation was carried out with $3 \mathrm{~h}$ reaction time. In this case, the desired unsymmetrically substituted bis-arylated product $\mathbf{4 . 1}$ was increased to $83 \%$ yield (Table 5, entry 2). Encouraged with this, a few more diarylations were attempted with different bismuth reagents. These reactions also furnished the corresponding unsymmetrically

Table 4: Bis-coupling of 2,3-dibromobenzofurans. ${ }^{\text {a }}$
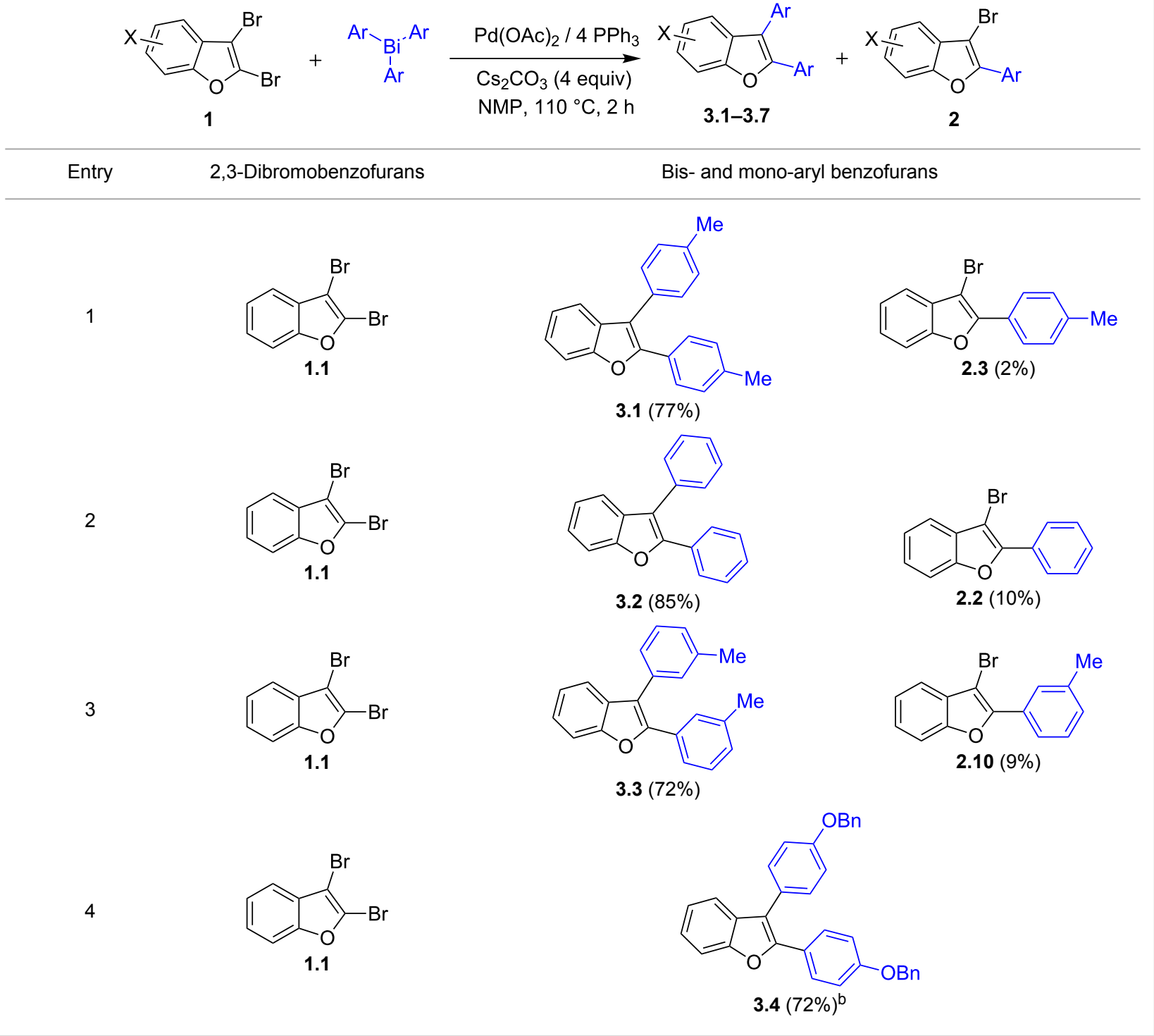
Table 4: Bis-coupling of 2,3-dibromobenzofurans. ${ }^{\text {a }}$ (continued)

5<smiles>Brc1oc2ccccc2c1Br</smiles>

1.1

6<smiles>Brc1oc2ccccc2c1Br</smiles>

1.1<smiles>Clc1ccc2oc(Br)c(Br)c2c1</smiles>

1.3<smiles>Fc1ccc(-c2oc3ccccc3c2-c2ccc(F)cc2)cc1</smiles>

$3.5(76 \%)$<smiles>COc1ccc(-c2oc3ccccc3c2-c2ccc(OC)cc2)cc1</smiles>

$3.6(82 \%)$

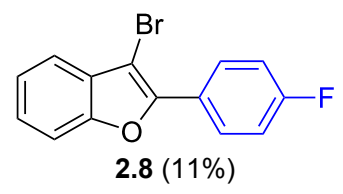

$2.8(11 \%)$<smiles>COc1ccc(-c2oc3ccccc3c2Br)cc1</smiles>

$2.1(10 \%)$

7<smiles>Cc1ccc(-c2oc3ccc(Cl)cc3c2-c2ccc(C)cc2)cc1</smiles>

$3.7(85 \%)^{b}$

aReaction conditions: 2,3-Dibromobenzofurans ( $0.375 \mathrm{mmol}, 1.5$ equiv), $\mathrm{BiAr}_{3}\left(0.25 \mathrm{mmol}, 1\right.$ equiv), $\mathrm{Pd}(\mathrm{OAc})_{2}(0.025 \mathrm{mmol}, 0.1 \mathrm{equiv}), \mathrm{PPh}_{3}$ ( $0.1 \mathrm{mmol}, 0.4$ equiv), $\mathrm{Cs}_{2} \mathrm{CO}_{3}\left(1 \mathrm{mmol}, 4\right.$ equiv), NMP $(3 \mathrm{~mL}), 110^{\circ} \mathrm{C}, 2 \mathrm{~h}$. Isolated yields based on three aryl couplings from $\mathrm{BiAr}_{3}$. Biaryl from $\mathrm{BiAr}_{3}$ formed in minor amounts. ${ }^{b}$ Mono-arylated product 2 not found.

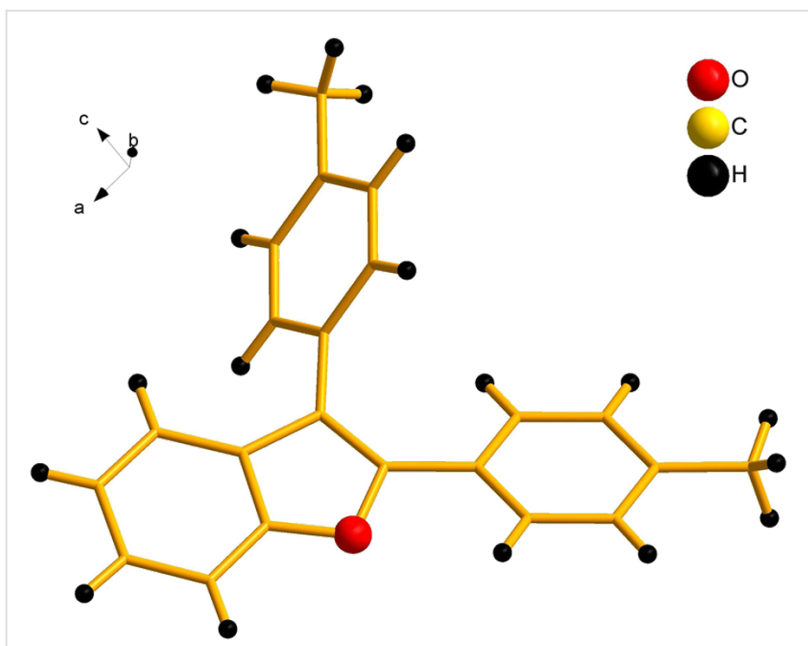

Figure 2: X-ray structure of bis-coupling product 3.1 (CCDC-1425338) [43].

substituted 2,3-diarylbenzofurans $\mathbf{4 . 2}$ and $\mathbf{4 . 3}$ in $81 \%$ and $73 \%$ yields (Table 5, entries 3 and 4) with minor amount of unreacted starting material 2-aryl-3-bromobenzofuran $\mathbf{2 . 1}$.

The good coupling reactivity of 2-aryl-3-bromobenzofurans to give unsymmetrically substituted 2,3-diarylbenzofurans was impressive. Hence, we were inquisitive to develop a poteconomic protocol to directly access these products minimizing the purification procedure after mono-arylation. Hence, it was performed in a stepwise manner (step 1 and step 2) in a one-pot operation without any intermediate isolation. These results are given in Table 6 . To elaborate, firstly we carried out the preparation of 2-aryl-3-bromobenzofuran in step 1 and it was followed by a second arylation at the 3-position as part of step 2 . This pot-economic approach afforded mixed 2,3-diarylbenzofurans 4.1-4.3 in 68-72\% yields (Table 6, entries 1-3). In all these reactions, we have also isolated the mono-aryl product from step 1 (2-aryl-3-bromobenzofuran, 2.1) in minor amounts. In fact, bis-arylated yields obtained in this one-pot operation are on par with that obtained in Table 5. This reflects the efficient nature of our established pot-economic protocol employing different triarylbismuth reagents. In literature, bis-aryl couplings with arylboronic acids were reported with good reactivity under different heating conditions for mono- and bis-arylations $[29,30]$. As mentioned before, our couplings employing triarylbismuths reacted on par with good reativity in addition to threefold coupling advantage with sub-stoichiometric loadings.

Further coupling study was carried out with 2,3,5-tribromobenzofuran (1.6) for the plausible threefold arylation 
Table 5: Cross-couplings of 2-aryl-3-bromobenzofurans. ${ }^{\text {a }}$

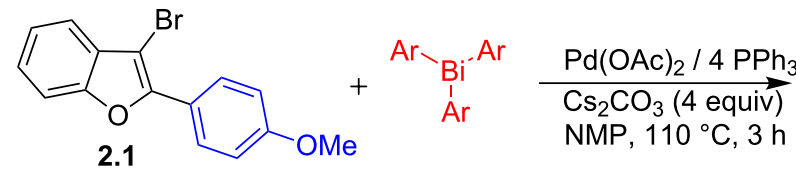

(3 equiv)

(1 equiv)

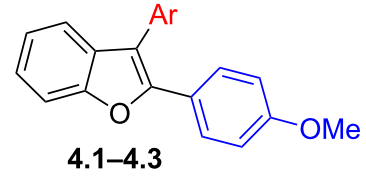

(3 equiv)

\begin{tabular}{|c|c|c|c|c|}
\hline Entry & $\mathrm{BiAr}_{3}$ & 2,3-Diarylbenzofurans & & Yield $(\%)^{b}$ \\
\hline 1 & & & 4.1 & $54(42)^{c}$ \\
\hline 2 & & & 4.1 & $83(11)$ \\
\hline 3 & & & 4.2 & $81(12)$ \\
\hline 4 & & & 4.3 & $73(11)$ \\
\hline
\end{tabular}

aReaction conditions: 2-Aryl-3-bromobenzofuran (2.1, 0.375 mmol, 3 equiv), $\mathrm{BiAr}_{3}$ (0.125 mmol, 1 equiv), $\mathrm{Pd}(\mathrm{OAc})_{2}(0.0125 \mathrm{mmol}, 0.1$ equiv), $\mathrm{PPh}$ (0.05 mmol, 0.4 equiv), $\mathrm{Cs}_{2} \mathrm{CO}_{3}\left(0.5 \mathrm{mmol}, 4\right.$ equiv), NMP $(3 \mathrm{~mL}), 110^{\circ} \mathrm{C}, 3 \mathrm{~h}$. Isolated yields based on three aryl couplings from BiAr 3 . Biaryl from $\mathrm{BiAr}_{3}$ formed in minor amounts. ${ }^{\mathrm{b}}$ Recovered 2.1 in parenthesis. ${ }^{C}$ Reaction time was $2 \mathrm{~h}$.

under Pd-coupling conditions (Table 7). With some experimentation, it was realized that threefold arylation of 2,3,5-tribromobenzofuran (1.6) using triarylbismuth reagent is possible to give 2,3,5-triarylbenzofuran in high yiled after a reaction time of $4 \mathrm{~h}$.

Hence, these couplings were conducted employing different triarylbismuth reagents. These tris-couplings afforded 2,3,5triarylated benzofurans 5.1-5.4 in 62-79\% yields (Table 7, entries 1-4). To note, all the three new aryl couplings were obtained in $4 \mathrm{~h}$ short duration of time in a one-pot operation and is synthetically advantageous. This reactivity is on par with simi- lar study reported with arylboronic acids [30]. Thus the present method of the preparation of 2,3,5-triarylbenzofurans is expected to serve as a useful protocol to access these skeletons in a facile manner.

\section{Conclusion}

We have established the couplings of 2,3-dibromobenzofurans and 2,3,5-tribromobenzofuran with high yields and faster reactivity using triarylbismuth reagents as atom-economic reagents. The Pd-catalyzed couplings carried out with triarylbismuths in sub-stoichiometric loadings allowed the synthesis of 2-aryl-3bromobenzofurans and symmetrically/unsymmetrically substi- 
Table 6: Pot-economic synthesis of unsymmetrical 2,3-diarylbenzofurans. ${ }^{\text {a }}$

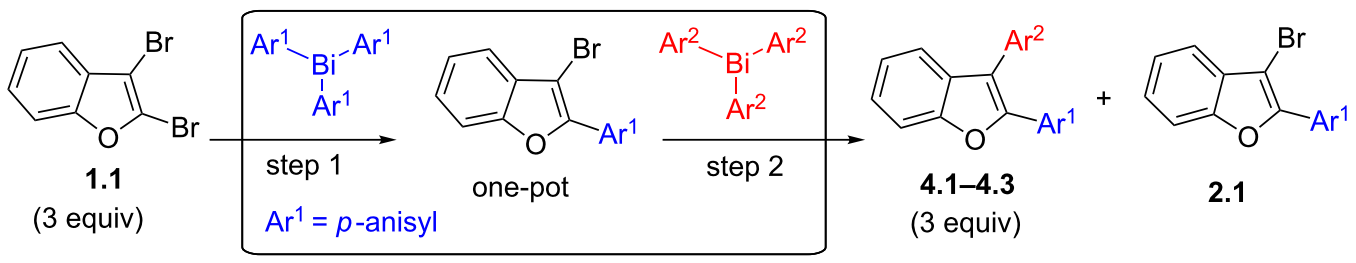
Entry
$\operatorname{BiAr}^{1} 3$
$\mathrm{BiAr}^{2} 3$
2,3-Diarylbenzofurans

1<smiles>COc1ccc(C(C)(C)Br)cc1</smiles><smiles>Cc1ccc(C)cc1</smiles><smiles>CCOc1ccc(C)cc1</smiles><smiles>COc1ccc(C(C)(C)Br)cc1</smiles><smiles>COc1ccc(C(C)(C)Br)cc1</smiles>

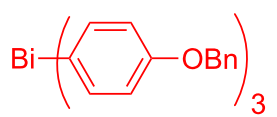<smiles>COc1ccc(-c2oc3ccccc3c2-c2ccc([N+](=O)[O-])cc2)cc1</smiles>

4.1 (72\%)<smiles>CCOc1ccc(-c2c(-c3ccc(OC)cc3)oc3ccccc23)cc1</smiles><smiles>COc1ccc(-c2oc3ccccc3c2Br)cc1</smiles>

$2.1(16 \%)$

$4.2(70 \%)$<smiles>COc1ccc(-c2oc3ccccc3c2-c2ccc(OCc3ccccc3)cc2)cc1</smiles><smiles>COc1ccc(-c2oc3ccccc3c2Br)cc1</smiles>

$4.3(68 \%)$

${ }^{a}$ Reaction conditions for Step 1: 2,3-Dibromobenzofuran (1.1, $0.375 \mathrm{mmol}, 3$ equiv), $\mathrm{BiAr}^{1}{ }_{3}\left(0.125 \mathrm{mmol}, 1\right.$ equiv), $\mathrm{Cs}_{2} \mathrm{CO}_{3}(0.5 \mathrm{mmol}, 4$ equiv), $\mathrm{Pd}(\mathrm{OAc})_{2}\left(0.0125 \mathrm{mmol}, 0.1\right.$ equiv), $\mathrm{PPh}_{3}\left(0.05 \mathrm{mmol}, 0.4\right.$ equiv), NMP, $90{ }^{\circ} \mathrm{C}, 2 \mathrm{~h}$; Reaction conditions for Step 2: BiAr ${ }_{3}$ ( $0.125 \mathrm{mmol}, 1$ equiv), $\mathrm{Cs}_{2} \mathrm{CO}_{3}$ (0.25 mmol, 2 equiv), $\mathrm{Pd}(\mathrm{OAc})_{2}\left(0.0062 \mathrm{mmol}, 0.05\right.$ equiv), $\mathrm{PPh}_{3}\left(0.025 \mathrm{mmol}, 0.2\right.$ equiv), NMP, $110^{\circ} \mathrm{C}, 2 \mathrm{~h}$. Isolated yields based on three aryl couplings from $\mathrm{BiAr}_{3}^{1}$ and $\mathrm{BiAr}_{3}^{2}$. Biaryl from $\mathrm{BiAr}_{3}$ formed in minor amounts.

Table 7: Tris-coupling of 2,3,5-tribromobenzofuran. ${ }^{a}$

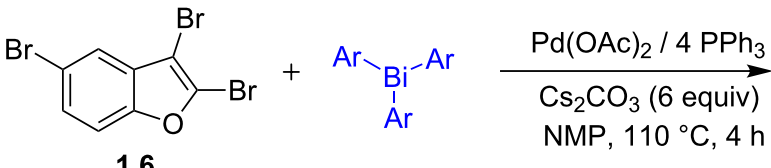

1.6<smiles>[Al]c1ccc2oc(Br)c(Br)c2c1</smiles>

$5.1-5.4$

Entry Yield (\%)


Table 7: Tris-coupling of 2,3,5-tribromobenzofuran. ${ }^{\text {a }}$ (continued)

2

3<smiles>Cc1cccc(C)c1</smiles>

4<smiles>Cc1ccc(C)cc1</smiles>

Me<smiles>Cc1ccc(-c2oc3ccc(-c4ccc(F)cc4)cc3c2-c2ccccc2)cc1</smiles><smiles>Cc1cccc(-c2ccc3oc(-c4cccc(C)c4)c(-c4cccc(C)c4)c3c2)c1</smiles>

5.3

aReaction conditions: 2,3,5-Tribromobenzofuran (1.6, $0.25 \mathrm{mmol}, 1$ equiv), $\mathrm{BiAr}_{3}$ (0.25 mmol, 1 equiv), $\mathrm{Pd}(\mathrm{OAc})_{2}\left(0.025 \mathrm{mmol}, 0.1\right.$ equiv), $\mathrm{PPh}{ }_{3}$ (0.1 mmol, 0.4 equiv), $\mathrm{Cs}_{2} \mathrm{CO}_{3}\left(1.5 \mathrm{mmol}, 6\right.$ equiv), NMP $(3 \mathrm{~mL}), 110^{\circ} \mathrm{C}, 4 \mathrm{~h}$. Isolated yields based on three aryl couplings from BiAr 3 . Biaryl from $\mathrm{BiAr}_{3}$ formed in minor amounts.

tuted 2,3-diarylbenzofurans in good to high yields. Additional threefold arylation of 2,3,5-tribromobenzofuran under Pd-catalyzed conditions afforded 2,3,5-triarylbenzofurans in high yields and in short reaction duration. The promising synthetic potential demonstrated in this study is expected to attract easy applications in structural elaborations of medicinally important benzofuran scaffolds.

\section{Supporting Information}

\section{Supporting Information File 1}

Experimental procedures, spectroscopic and analytical data of all compounds.

[http://www.beilstein-journals.org/bjoc/content/ supplementary/1860-5397-12-195-S1.pdf]

\section{Supporting Information File 2}

${ }^{1} \mathrm{H},{ }^{13} \mathrm{C}$ NMR spectra of all compounds.

[http://www.beilstein-journals.org/bjoc/content/ supplementary/1860-5397-12-195-S2.pdf]

\section{Acknowledgements}

We thank the Council of Scientific and Industrial Research (CSIR) New Delhi (No. 02(0091)/12/EMR-II) for the financial support. J. B. T. and V. N. M. thank the University Grants Commission (UGC) New Delhi and Council of Scientific and
Industrial Research (CSIR), New Delhi for research fellowship respectively.

\section{References}

1. Teo, C. C.; Kon, O. L.; Sim, K. Y.; Ng, S. C. J. Med. Chem. 1992, 35, 1330-1339. doi:10.1021/jm00086a002

2. Halabalaki, M.; Aligiannis, N.; Papoutsi, Z.; Mitakou, S.; Moutsatsou, P.; Sekeris, C.; Skaltsounis, A.-L. J. Nat. Prod. 2000, 63, 1672-1674. doi:10.1021/np000071b

3. Alonen, A.; Jansson, J.; Kallonen, S.; Kiriazis, A.; Aitio, O.; Finel, M.; Kostiainen, R. Bioorg. Chem. 2008, 36, 148-155. doi:10.1016/j.bioorg.2008.02.004

4. Nevagi, R. J.; Dighe, S. N.; Dighe, S. N. Eur. J. Med. Chem. 2015, 97, 561-581. doi:10.1016/j.ejmech.2014.10.085

5. Radadiya, A.; Shah, A. Eur. J. Med. Chem. 2015, 97, 356-376. doi:10.1016/j.ejmech.2015.01.021

6. Khanam, H.; Shamsuzzaman. Eur. J. Med. Chem. 2015, 97, 483-504. doi:10.1016/j.ejmech.2014.11.039

7. He, Y.; Xu, J.; Yu, Z.-H.; Gunawan, A. M.; Wu, L.; Wang, L.; Zhang, Z.-Y. J. Med. Chem. 2013, 56, 832-842. doi:10.1021/jm301781p

8. Gfesser, G. A.; Faghih, R.; Bennani, Y. L.; Curtis, M. P.; Esbenshade, T. A.; Hancock, A. A.; Cowart, M. D. Bioorg. Med. Chem. Lett. 2005, 15, 2559-2563. doi:10.1016/j.bmcl.2005.03.047

9. Buchi, G.; Chu, P.-S. J. Org. Chem. 1978, 43, 3717-3719. doi:10.1021/jo00413a018

10. Kraus, G. A.; Gupta, V. Tetrahedron Lett. 2009, 50, 7180-7183. doi:10.1016/j.tetlet.2009.10.040

11. Simonetti, S. O.; Larghi, E. L.; Bracca, A. B. J.; Kaufman, T. S. Nat. Prod. Rep. 2013, 30, 941-969. doi:10.1039/c3np70014c 
12. Zhang, F.; Guo, L.; Hu, W.; Jia, Y. Tetrahedron 2015, 71, 3756-3762. doi:10.1016/j.tet.2014.06.095

13. Rao, M. L. N.; Awasthi, D. K.; Banerjee, D. Tetrahedron Lett. 2010, 51, 1979-1981. doi:10.1016/j.tetlet.2010.02.018

14. Wu, D.; Mei, H.; Tan, P.; Lu, W.; Zhu, J.; Wang, W.; Huang, J.; Li, J. Tetrahedron Lett. 2015, 56, 4383-4387. doi:10.1016/j.tetlet.2015.05.093

15. Murakami, K.; Yorimitsu, H.; Osuka, A. Angew. Chem., Int. Ed. 2014, 53, 7510-7513. doi:10.1002/anie.201403288

16. Tsuji, H.; Mitsui, C.; Sato, Y.; Nakamura, E. Adv. Mater. 2009, 21 , 3776-3779. doi:10.1002/adma.200900634

17. Chiummiento, L.; Funicello, M.; Lopardo, M. T.; Lupattelli, P.; Choppin, S.; Colobert, F. Eur. J. Org. Chem. 2012, 188-192. doi:10.1002/ejoc.201101422

18. Kim, I.; Choi, J. Org. Biomol. Chem. 2009, 7, 2788-2795. doi:10.1039/b901911a

19. Huang, K.-S.; Wang, Y.-H.; Li, R.-L.; Lin, M. Phytochemistry 2000, 54, 875-881. doi:10.1016/S0031-9422(00)00151-5

20. Shi, W.; Lowary, T. L. Bioorg. Med. Chem. 2011, 19, 1779-1789. doi:10.1016/j.bmc.2011.01.014

21. Li, S.; Li, W.; Wang, Y.; Asada, Y.; Koike, K. Bioorg. Med. Chem. Lett. 2010, 20, 5398-5401. doi:10.1016/j.bmcl.2010.07.110

22. Alvey, L.; Prado, S.; Saint-Joanis, B.; Michel, S.; Koch, M.; Cole, S. T.; Tillequin, F.; Janin, Y. L. Eur. J. Med. Chem. 2009, 44, 2497-2505. doi:10.1016/j.ejmech.2009.01.017

23. Cho, C.-H.; Neuenswander, B.; Lushington, G. H.; Larock, R. C. J. Comb. Chem. 2008, 10, 941-947. doi:10.1021/cc800120y

24. Colobert, F.; Castanet, A.-S.; Abillard, O. Eur. J. Org. Chem. 2005, 3334-3341. doi:10.1002/ejoc.200500166

25. Markina, N. A.; Chen, Y.; Larock, R. C. Tetrahedron 2013, 69, 2701-2713. doi:10.1016/j.tet.2013.02.003

26. Li, H.; Liu, J.; Yan, B.; Li, Y. Tetrahedron Lett. 2009, 50, 2353-2357. doi:10.1016/j.tetlet.2009.02.204

27. Guilarte, V.; Castroviejo, M. P.; Álvarez, E.; Sanz, R. Beilstein J. Org. Chem. 2011, 7, 1255-1260. doi:10.3762/bjoc.7.146

28. Rossy, C.; Fouquet, E.; Felpin, F.-X. Beilstein J. Org. Chem. 2013, 9, 1426-1431. doi:10.3762/bjoc.9.160

29. Hung, N. T.; Hussain, M.; Malik, I.; Villinger, A.; Langer, P. Tetrahedron Lett. 2010, 51, 2420-2422. doi:10.1016/j.tetlet.2010.02.141

30. Hussain, M.; Hung, N. T.; Abbas, N.; Khera, R. A.; Malik, I.; Patonay, T.; Kelzhanova, N.; Abilov, Z. A.; Villinger, A.; Langer, P. J. Heterocycl. Chem. 2015, 52, 497-505. doi:10.1002/jhet.2083

31. Bach, T.; Bartels, M. Synlett 2001, 1284-1286. doi:10.1055/s-2001-16052

32. Bach, T.; Bartels, M. Synthesis 2003, 925-939. doi:10.1055/s-2003-38695

33. Bach, T.; Bartels, M. Tetrahedron Lett. 2002, 43, 9125-9127. doi:10.1016/S0040-4039(02)02287-6

34. Hussain, M.; Hung, N. T.; Langer, P. Tetrahedron Lett. 2009, 50, 3929-3932. doi:10.1016/j.tetlet.2009.04.069

35. Rao, M. L. N.; Awasthi, D. K.; Talode, J. B. Tetrahedron Lett. 2012, 53, 2662-2666. doi:10.1016/j.tetlet.2012.03.059

36. Shimada, S.; Rao, M. L. N. Transition-Metal Catalyzed C-C Bond Formation Using Organobismuth Compounds. In Bismuth-Mediated Organic Reactions; Ollevier, T., Ed.; Topics in Current Chemistry, Vol. 311; Springer: Berlin, Germany, 2011; pp 199-228. doi:10.1007/128_2011_202

37. Suzuki, H.; Matano, Y., Eds. Organobismuth chemistry; Elsevier: Amsterdam, Netherlands, 2001.
38. Rao, M. L. N.; Jadhav, D. N.; Dasgupta, P. Org. Lett. 2010, 12, 2048-2051. doi:10.1021/ol1004164

39. Rao, M. L. N.; Dhanorkar, R. J. RSC Adv. 2016, 6, 1012-1017. doi:10.1039/C5RA23311A

40. Hébert, M.; Petiot, P.; Benoit, E.; Dansereau, J.; Ahmad, T.; Le Roch, A.; Ottenwaelder, X.; Gagnon, A. J. Org. Chem. 2016, 81, 5401-5416. doi:10.1021/acs.joc.6b00767

41. Rao, M. L. N.; Talode, J. B. Asian J. Org. Chem. 2016, 5, 98-106. doi:10.1002/ajoc.201500334

42. Rao, M. L. N.; Jadhav, D. N.; Banerjee, D. Tetrahedron 2008, 64, 5762-5772. doi:10.1016/j.tet.2008.04.011

43. CCDC-1425338 contains all crystallographic details of this publication and is available free of charge at http://www.ccdc.cam.ac.uk/conts/retrieving.html or can be ordered from the following address: Cambridge Crystallographic Data Centre, 12 Union Road, GB-Cambridge CB21EZ; Fax: (+44)1223-336-033; or deposit@ccdc.cam.ac.uk

\section{License and Terms}

This is an Open Access article under the terms of the Creative Commons Attribution License (http://creativecommons.org/licenses/by/4.0), which permits unrestricted use, distribution, and reproduction in any medium, provided the original work is properly cited.

The license is subject to the Beilstein Journal of Organic Chemistry terms and conditions:

(http://www.beilstein-journals.org/bjoc)

The definitive version of this article is the electronic one which can be found at: doi:10.3762/bjoc. 12.195 